\title{
Influences of Organic Carbon Supply Rate on Uranium Bioreduction in Initially Oxidizing, Contaminated Sediment
}

Tetsu K. Tokunaga* ${ }^{1}$, Jiamin Wan ${ }^{1}$, Yongman Kim ${ }^{1}$, Rebecca A. Daly ${ }^{2}$, Eoin L. Brodie ${ }^{1}$, Terry C. Hazen ${ }^{1}$, Don Herman ${ }^{2}$, and Mary K. Firestone ${ }^{1,2}$

\author{
*Corresponding author phone (510) 486-7176; e-mail: tktokunaga@1bl.gov \\ ${ }^{1}$ Lawrence Berkeley National Laboratory, Berkeley, California 94720 \\ ${ }^{2}$ University of California, Berkeley, California 94720
}

\begin{abstract}
Remediation of uranium (U) contaminated sediments through in-situ stimulation of bioreduction to insoluble $\mathrm{UO}_{2}$ is a potential treatment strategy under active investigation. Previously, we found that newly reduced U(IV) can be reoxidized under reducing conditions sustained by a continuous supply of organic carbon (OC) because of residual reactive Fe(III) and enhanced U(VI) solubility through complexation with carbonate generated through OC oxidation. That finding motivated this investigation directed at identifying a range of OC supply rates that is optimal for establishing $\mathrm{U}$ bioreduction and immobilization in initially oxidizing sediments. The effects of OC supply rate, from 0 to $580 \mathrm{mmol} \mathrm{OC} \mathrm{(kg} \mathrm{sediment)}{ }^{-1} \mathrm{year}^{-1}$, and OC form (lactate and acetate) on $\mathrm{U}$ bioreduction were tested in flow-through columns containing U-contaminated sediments. An intermediate supply rate on the order of 150 mmol OC $(\mathrm{kg} \text { sediment })^{-1}$ year $^{-1}$ was determined to be most effective at immobilizing $\mathrm{U}$. At lower OC supply rates, $\mathrm{U}$ bioreduction was not achieved, and U(VI) solubility was enhanced by complexation with carbonate (from OC
\end{abstract}


oxidation. At the highest OC supply rate, resulting highly carbonate-enriched solutions also supported elevated levels of $\mathrm{U}(\mathrm{VI})$, even though strongly reducing conditions were established. Lactate and acetate were found to have very similar geochemical impacts on effluent $U$ concentrations (and other measured chemical species), when compared at equivalent OC supply rates. While the catalysts of $\mathrm{U}(\mathrm{VI})$ reduction to $\mathrm{U}(\mathrm{IV})$ are presumably bacteria, the composition of the bacterial community, the Fe reducing community, and the sulfate reducing community had no direct relationship with effluent $\mathrm{U}$ concentrations. The OC supply rate has competing effects of driving reduction of $\mathrm{U}(\mathrm{VI})$ to low solubility $\mathrm{U}(\mathrm{IV})$ solids, as well as causing formation of highly soluble U(VI)-carbonato complexes. These offsetting influences will require careful control of OC supply rates in order to optimize bioreduction-based U stabilization.

\section{Introduction}

Uranium (U) contamination of soils and sediments has become a critical problem at numerous sites used for production of nuclear fuels and weapons. Various strategies for remediation and long-term stewardship of U-contaminated sediments and groundwaters are under active investigation, including approaches based on in-situ bioreduction of U (1-3). The goal of in-situ bioreduction is to stimulate indigenous microbial communities to reduce soluble U(VI) to insoluble $\mathrm{U}(\mathrm{IV})$ solids, thereby decreasing $\mathrm{U}$ concentrations in groundwaters below the

Maximum Contaminant Level (MCL, for ${ }^{238} \mathrm{U}=10 \mathrm{pCi} \mathrm{L}^{-1}=0.13 \mu \mathrm{M}$ ). A variety of microorganisms capable of reducing $\mathrm{U}(\mathrm{VI})$ have been identified (3), including Fe(III)-reducers (1) and sulfate reducers $(4,5)$. In order to accelerate $U$ bioreduction, organic carbon (OC) is provided as an electron donor and growth substrate for indigenous microbial communities. However, these beneficial influences of OC addition can be offset by increases in inorganic $\mathrm{C}$ 
(IC) concentrations resulting from stimulating microbial respiration. Increased (bi)carbonate concentrations drive aqueous $\mathrm{U}(\mathrm{VI})$ concentrations to higher levels through formation of stable $\mathrm{U}(\mathrm{VI})$ carbonato complexes, even under reducing conditions and in the presence of active Ureducing bacterial communities $(6,7)$. The impact of OC oxidation on enhanced U(VI)carbonate solubility under well-established reducing conditions was recently demonstrated. A subset of sediment columns from our previous work (6) was maintained under reducing conditions, then switched to individually different OC supply rates. Under sustained reduction, lower U solubility was achieved with lower OC supply rate because of decreased formation of soluble U(VI)-carbonate complexes, while increased OC supply rates lead to greatly increased U concentrations for the same reason (8). Thus the success of in situ U bioreduction in sediments is not assured by simply supplying $\mathrm{OC}$ at rates high enough to generate reducing conditions. This previously unrecognized side effect of OC-stimulated bioreduction can impair attempts at remediating groundwater to below the $\mathrm{U} \mathrm{MCL}$, and points to the importance of determining whether an optimal, intermediate level of OC supply exists for effectively reducing aqueous $\mathrm{U}$ concentrations in initially oxidizing, contaminated sediments.

Stimulation of in-situ U bioreduction can also depend on the form of OC supplied and sediment geochemistry. Under acidic conditions, glucose has been reported to be more effective in stimulating $\mathrm{Fe}(\mathrm{III})$-reducing bacteria than lactate and acetate (9). Acetate has been used in numerous tests because of its efficiency in stimulating Fe-reducing microbial populations (2). Ethanol has been reported to promote more rapid $\mathrm{U}(\mathrm{VI})$ reduction than acetate or lactate in a batch study (10), and has been used to stimulate U bioreduction in column (11) and field (10) experiments. For Desulfovibrio desulfuricans, reduction rates of U(VI) in multidentate aliphatic 
complexes were slower than in monodentate aliphatic complexes, but with Shewanella alga faster $\mathrm{U}$ reduction rates were achieved with multidentate aliphatics (12).

This study was conducted to test the hypothesis that $\mathrm{U}$ bioreduction and removal from pore waters in initially oxidizing sediments will be most effective with an intermediate (rather than high) rate of OC supply, because microbial oxidation of excessive OC favors the formation of soluble $\mathrm{U}(\mathrm{VI})$-carbonate complexes. While primarily relying on column experiments, geochemical modeling was also performed for characteristic conditions in order to gain more insights into impacts of increased IC. In addition to this primary goal, this study sought to determine whether responses differ when the OC is supplied in the form of either acetate or lactate (two carboxylic acids used in various studies on $\mathrm{U}$ biorection), and whether remobilization of bioreduced $\mathrm{U}$ is directly dependent on the composition of the microbial community.

\section{Materials and Methods}

Sediment columns. Historically U-contaminated sediment was provided by the U.S. Department of Energy's Environmental Remediation Science Program (ERSP) Field Research Center (FRC) at Oak Ridge National Laboratory. This sediment came from the same contaminated area from which samples were collected for our previous study (6), and had a total U concentration of 1.08 mmol kg ${ }^{-1}$ (X-ray fluorescence analysis, XRF). Geochemical analyses of the sediment are provided in Supporting Information Table S1. Moist sediment was passed through a $4.75 \mathrm{~mm}$ sieve and homogenized prior to packing into 26 columns, each to a porosity of 0.51 . The 200 $\mathrm{mm}$ long, $31.5 \mathrm{~mm}$ inner diameter polycarbonate columns were similar to those used previously (6). Platinum wire redox electrodes were embedded into the walls of most columns at distances 
of 50,100, and $150 \mathrm{~mm}$. Redox potentials were periodically measured with Pt electrodes referenced to a calomel electrode tapped into the outflow end of each column. Columns for one set of lactate treatments (from 0 up to $100 \mathrm{mM} \mathrm{OC}$ ) were designed with Kapton windows in order to obtain X-ray absorption spectra of $\mathrm{U}, \mathrm{Fe}$, and $\mathrm{Mn}$ (13). A parallel set of identical columns (without Pt electrodes) was run simultaneously for microbial community analysis. All columns were kept in an $\mathrm{N}_{2}$-purged glovebox throughout the study.

Influent and effluent solutions. The background ionic composition of influent solutions was based on the composition of an uncontaminated groundwater from the Oak Ridge FRC. Its major ion chemistry consisted of $0.83 \mathrm{mM} \mathrm{Ca}^{2+}, 0.20 \mathrm{mM} \mathrm{Mg}^{2+}, 2.00 \mathrm{mM} \mathrm{Na}^{+}, 0.10 \mathrm{mM} \mathrm{K}^{+}, 2.1$ $\mathrm{mM} \mathrm{Cl}^{-}, 1.00 \mathrm{mM} \mathrm{HCO}_{3}^{-}, 0.50 \mathrm{mM} \mathrm{SO}_{4}^{2-}$, and $0.05 \mathrm{mM} \mathrm{NO}_{3}^{-}$, had an ionic strength of $5.68 \mathrm{mM}$, and $\mathrm{pH}=7.3$. Low levels of $\mathrm{NO}_{3}{ }^{-}$and $\mathrm{SO}_{4}{ }^{2-}$ were included in these solutions because of their natural occurrence in groundwater, therefore their likely influence on remediation strategies that involve injection of OC-amended local groundwater. Na-lactate and Na-acetate were added to these salt solutions to contain $0,3,10,30$, and $100 \mathrm{mM} \mathrm{OC}$, with all solutions prepared with filtered deionized water in autoclaved containers. Duplicate columns were run for $0 \mathrm{mM} \mathrm{OC}$, and for each lactate and acetate concentration $(3,10,30,100 \mathrm{mM})$. Solutions were supplied via syringe pumps at an average pore water velocity of $8.2 \mathrm{~mm} \mathrm{day}^{-1}$ (24 day residence time). After supplying columns with 2 pore volumes $(1 \mathrm{PV}=79.5 \mathrm{~mL})$ of the $0 \mathrm{mM} \mathrm{OC}$ solution, infusion with different OC concentration solutions (including continuation of one column with $0 \mathrm{mM} \mathrm{OC}$ ) was initiated. The combination of influent $\mathrm{OC}$ concentrations and pump rate yielded columnaveraged supply rates ranging from 0 to $1.4 \mathrm{mmol} \mathrm{OC} \mathrm{kg}^{-1} \mathrm{day}^{-1}$. Effluents were collected using a fraction collector, and periodically analyzed for U (kinetic phosphorescence analyzer KPA-11, 
Chemchek), OC and inorganic C (IC) (TOC-V-CSH, Shimadzu), and other major elements (ICP).

Geochemical modeling. Increases in bicarbonate concentrations and $\mathrm{P}_{\mathrm{CO} 2}$ resulting from $\mathrm{OC}$ oxidation affect aqueous $\mathrm{U}$ concentrations through increasing concentrations of numerous $\mathrm{U}(\mathrm{VI})$ carbonate complexes. Assuming local equilibrium, changes in effluent $U$ species response to increases in $\mathrm{P}_{\mathrm{CO} 2}$ during the late stage in this experiment (12 to $16 \mathrm{PV}$ ) were calculated with PHREEQC2.12 (14), using the Nuclear Energy Agency database (15) and the stability constants for aqueous $\mathrm{CaUO}_{2}\left(\mathrm{CO}_{3}\right)_{3}{ }^{2-}$ and $\mathrm{Ca}_{2} \mathrm{UO}_{2}\left(\mathrm{CO}_{3}\right)_{3}$ of Dong and Brooks (16). The $\mathrm{pH}$ and major ion composition characteristic of late stage effluents were used for these calculations as described in Supporting Information. Although some U(VI)-OC complexes are likely to be present in effluents, they were not included in calculations because preliminary simulations showed that the U(VI)-carbonate complexes were overwhelmingly dominant. For oxidizing conditions, the modeled total $\mathrm{U}(\mathrm{VI})$ concentration was equated with the exchangeable $\mathrm{U}$ determined by the (bi)carbonate method recommended by Kohler et al. (17), because significant fractions of the total $\mathrm{U}$ inventory in contaminated sediments can be relatively refractory. The (bi)carbonateextractable $\mathrm{U}$ amounted to $59.2 \pm 0.4 \%$ of the total $\mathrm{U}$, and may overestimate the exchangeable inventory because the extractions were done on samples that became dry during storage. U(VI) sorption was assumed to occur on ferrihydrite-like sites, with the citrate-dithionite-bicarbonate extracted Fe used as an estimate of ferrihydrite Fe (18). Values of ferrihydrite specific surface area, site densities and binding constants (Supporting Information) used in generalized two-layer model calculations are taken from Dzombak and Morel (19), Parkhurst and Appelo (14), Appelo et al. (20), and Payne (21). For the reducing case, U solubility was assumed to be controlled by $\mathrm{UO}_{2}(\mathrm{am})$. Although sorption of $\mathrm{U}(\mathrm{VI})$ under reducing conditions is likely to be important (22), 
surface complexation was not included in these calculations because of large uncertainties associated with binding site densities.

DNA extraction and amplification. Nucleic acids were extracted from sediment samples collected from the set of columns designated for microbial analysis at 5.9 and 12.1 PV relative to OC start, near the outlet of the columns. DNA was extracted using a modification of the Fast DNA SPIN Kit for Soil (MP Biomedicals, Irvine, CA) (see supporting information). 16S rDNA gene amplification was performed by using primers 27F (5'-AGAGTTTGATCCTGGCTCAG3') AND 1492R (5'-GGTTACCTTGTTACGACTT-3'). Each PCR reaction contained 1x Ex Taq buffer (Takara Bio Inc., Japan), 1.25 U Ex Taq polymerase, $200 \mu \mathrm{M}$ each dNTP, $2.5 \mu \mathrm{g}$ BSA, $300 \mathrm{~nm}$ each primer and $100 \mathrm{ng}$ DNA template in a final volume of $50 \mu \mathrm{l}$. PCR conditions were $95^{\circ} \mathrm{C}(3 \mathrm{~min})$, followed by 25 cycles $95^{\circ} \mathrm{C}(30 \mathrm{~s}), 48-58^{\circ} \mathrm{C}(25 \mathrm{~s}), 72^{\circ} \mathrm{C}(2 \mathrm{~min})$, followed by a final extension $72^{\circ} \mathrm{C}(10 \mathrm{~min})$. Each DNA extract was amplified in 8 replicate $50 \mu \mathrm{l}$ reactions spanning a range of annealing temperatures between $48-58^{\circ} \mathrm{C}$. Amplicons from the 8 reactions were pooled, precipitated with isopropanol, washed with ethanol, and resuspended to $50 \mu 1$.

High-density oligonucleotide array analyses. From each pool of 16S rRNA gene amplicons, 2 $\mu \mathrm{g}$ was prepared for hybridization to the PhyloChip as previously described (7). Target fragmentation, biotin labeling, PhyloChip hybridization, scanning and staining were as described by Brodie et al. (7), while background subtraction, noise calculation, and detection and quantification criteria were as reported in Brodie et al. (7) with some minor exceptions. For a probe pair to be considered positive, the difference in intensity between the perfect match (PM) and mismatch (MM) probes must be at least 130 times the squared noise value $(N)$. A taxon was considered present when $90 \%$ or more of the probe pairs for its corresponding probe set were 
positive (positive fraction, $\geq 0.90$ ). The OTU (operational taxonomic group) grouping was used for PhyloChip output, which consists of one or more sequences with typically $97 \%$ to $100 \%$ sequence homology.

Statistical analysis of bacterial communities. Two functional groups were identified as a subset of the PhyloChip results, iron-reducers and sulfate-reducers. Only taxa that have been previously shown to carry out these functions were considered, although it is likely that other taxa fall into these functional groups. OTUs that conserve energy by iron-reduction were identified by referencing Lovley et al. (23) (see Table S4 in supporting information). OTUs that are capable of sulfate-reduction were identified by referencing Rabus et al. (24) (see Table S5 in supporting information). For analysis of the bacterial communities, nonmetric multidimensional scaling (NMDS) was used within the community ecology package vegan 1.8-5 for R (25). The function 'metaMDS' from the vegan library was used, which applies Bray-Curtis dissimilarities as a measure of ecological distance and first performs a square root transformation and then a Wisconsin double standardization (26). To determine if community structures were associated with local column redox, average column redox, IC effluent concentrations or U effluent concentrations, linear regressions were performed against NMDS axis scores and environmental variables. U and IC concentrations were measured from the replicate set of columns designated for microbial analysis at PV 5.6 and 12.0 relative to OC start. Average redox values were calculated as the average of 6 redox measurements ( 3 locations within duplicate columns), designated as "Eh average"; local redox values were calculated as the average of 2 redox measurements ("top" location within duplicate columns), designated as "Eh local". "Eh local" is the portion of the column from which sediments were sampled for microbial nucleic acid analysis. Eh measurements were taken at PV 5.8 and 12.7 relative to OC start. Bacterial 
community analyses were performed on identical, replicate sets of columns that did not have Pt electrodes, and thus have no direct Eh measurements.

\section{Results and Discussion}

Redox potentials. Redox potential measurements indicated that oxidizing conditions were characteristic of all columns at the beginning of the experiment. Average redox potentials (relative to the standard $\mathrm{H}$ electrode reference) are shown as time trends in Figure 1a. Each data point in Figure 1a is an average of 6 redox measurements (3 locations within duplicate columns) obtained at a specific time. These time trends generally show responses to each of the different levels of OC supply rate, but insensitivity to whether OC was delivered as lactate or acetate. After about 100 days of exposure to different solutions, redox potentials within individual columns became fairly stable, with more reducing conditions measured within sediments with higher rates of OC supply. Without infusion of OC, and even with OC supplied at 0.04 mmol $\mathrm{kg}^{-1}$ day $^{-1}(3 \mathrm{mM}$ OC), redox potentials measurements in sediments remained moderately oxidizing. Calculated Eh values for various redox couples, based on conditions indicated in the caption, are shown along the y-axis. The time trends in redox potentials suggest that the 0.14 mmol kg ${ }^{-1}$ day $^{-1}$ (10 mM OC) sediments are insufficiently reducing to immobilize U as U(IV), whereas the 0.42 and $1.4 \mathrm{mmol} \mathrm{kg}^{-1}$ day $^{-1}$ (30 and $100 \mathrm{mM} \mathrm{OC)} \mathrm{sediments} \mathrm{are.}$

Within individual sediment columns, relatively stable redox profiles were measured after about 130 days of infusion. Uniformly oxidizing conditions without infusion of OC, uniformly reducing conditions in the 0.42 and $1.4 \mathrm{mmol} \mathrm{kg}^{-1}$ day $^{-1}$ (30 and $100 \mathrm{mM} \mathrm{OC)} \mathrm{sediments,} \mathrm{and}$ redox gradients in the 0.14 and $0.04 \mathrm{mmol} \mathrm{kg}^{-1}$ day $^{-1}$ (10 and $3 \mathrm{mM} \mathrm{OC)} \mathrm{sediments} \mathrm{are} \mathrm{shown} \mathrm{in}$ time-averaged (from 5.9 to $12.7 \mathrm{PV}$ ) data in Figure $1 \mathrm{~b}$. 

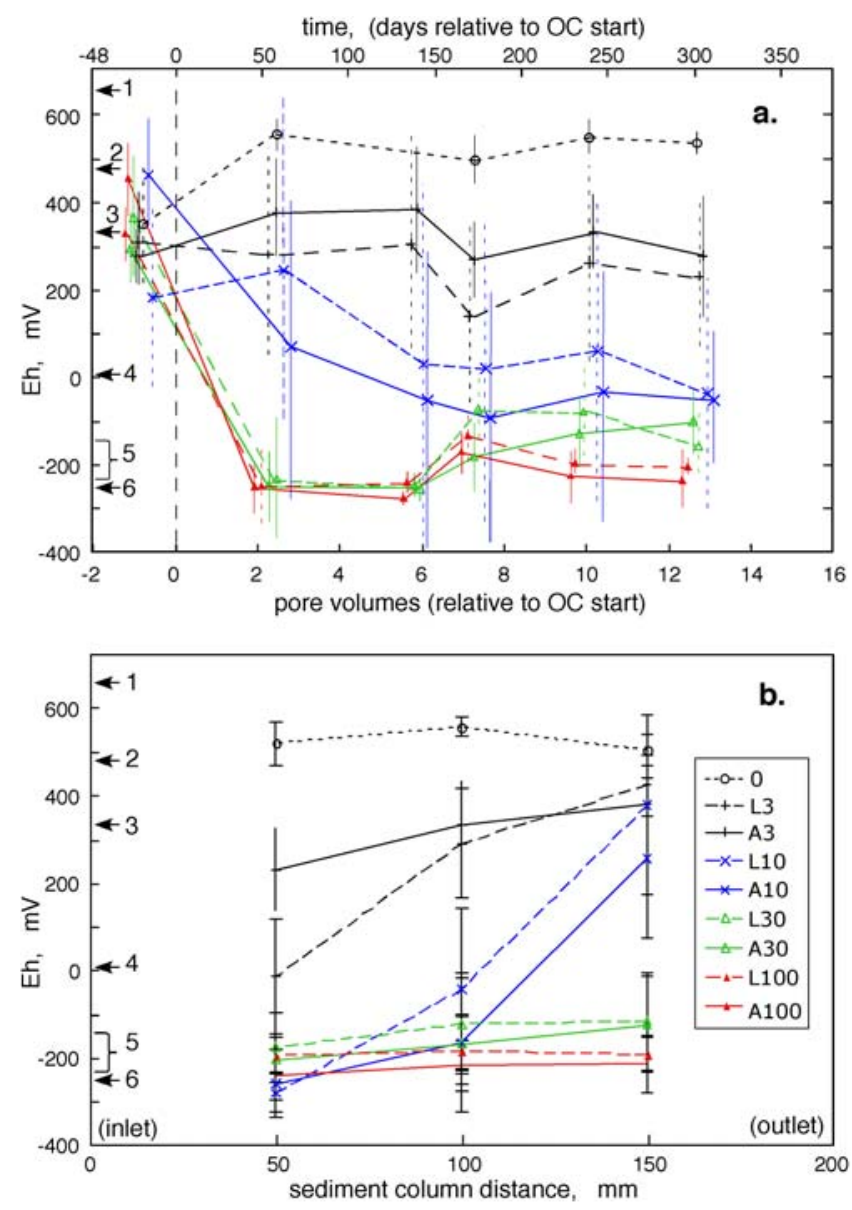

Figure 1. Redox potentials measured within sediment columns (referenced to standard $\mathrm{H}$ electrode). (a.) Time trends of column-averaged redox potentials. Numbers following "L" (lactate) and "A" (acetate) denote influent OC concentrations in $\mathrm{mM}$. Data points are slightly offset along the time axis for clarity in cases with overlapping values. (b.) Redox potential profiles within sediment columns at later stages (times $>100$ days). Range bars indicate standard deviations. Also shown along the Eh axis are calculated potentials (at $\mathrm{pH} 7.5$, characteristic of effluents) for (1) nitrate reduction $\left(\mathrm{NO}_{3}{ }^{-}=1 \mu \mathrm{M}, \mathrm{P}\left(\mathrm{N}_{2}\right)=0.8 \mathrm{~atm}\right)$, (2) $\mathrm{Mn}(\mathrm{IV})$ reduction (pyrolusite, $\mathrm{Mn}^{2+}=10 \mu \mathrm{M}$ ), (3) nitrite reduction to ammonia (equimolar $\mathrm{N}$ species), (4) $\mathrm{Fe}(\mathrm{III})$ reduction (ferrihydrite, $\mathrm{Fe}^{2+}=1 \mu \mathrm{M}$ ), (5) $\mathrm{U}(\mathrm{VI})$ reduction $\left(\mathrm{Ca}_{2} \mathrm{UO}_{2}\left(\mathrm{CO}_{3}\right)_{3}=1 \mathrm{mM}, \mathrm{U}(\mathrm{IV})=\right.$ $\mathrm{UO}_{2}(\mathrm{am}), \mathrm{pCO}_{2}=2$ to 1.5 and $\mathrm{Ca}^{2+}=0.1$ to $\left.1.0 \mathrm{mM}\right)$, and (6) sulfate reduction to pyrite $(1 \mu \mathrm{M}$ $\left.\mathrm{Fe}^{2+}, 0.1 \mathrm{mM} \mathrm{SO}_{4}^{2-}\right)$. 
Carbon in effluents. The total dissolved $\mathrm{C}$ concentrations in effluents from the sediment columns were roughly proportional to their respective influent OC concentrations. Total dissolved OC (TOC) and inorganic C (TIC) concentrations in effluents from the columns supplied with lactate and acetate (0 to $100 \mathrm{mM})$ are shown in Figures 2a-d. The breakthrough curves for TOC reflect greater degradation of lactate (Figures 2a and 2c) than acetate (Figures $2 b$ and 2d) up to about 140 days (6 PV), after which both OC forms were oxidized at similar rates. Sediments receiving solutions lacking either form of OC nevertheless had average effluent TIC of $2.5 \mathrm{mM}(1.5 \mathrm{mM}$ in excess of influent bicarbonate levels), indicative of native sediment organic matter oxidation. Although nearly all of the OC supplied after about 200 days (9 PV) was depleted in effluents, the effluent TIC accounts for only about $50 \%$ of the $\mathrm{C}$ balance at the higher supply rates. This is similar to the TIC/TOC balance in effluents measured in a previous experiment (sediment supplied with $32 \mathrm{mM}$ lactate) (6). Effluents from the present experiment contained low concentrations of $\mathrm{CH}_{4}(\leq 0.01 \mathrm{mM})$ for systems supplied with $\leq 10 \mathrm{mM} \mathrm{OC}$, and variable but elevated $\mathrm{CH}_{4}$ (2 to $26 \mathrm{mM}$ ) for systems supplied with 30 and $100 \mathrm{mM} \mathrm{OC}$. 

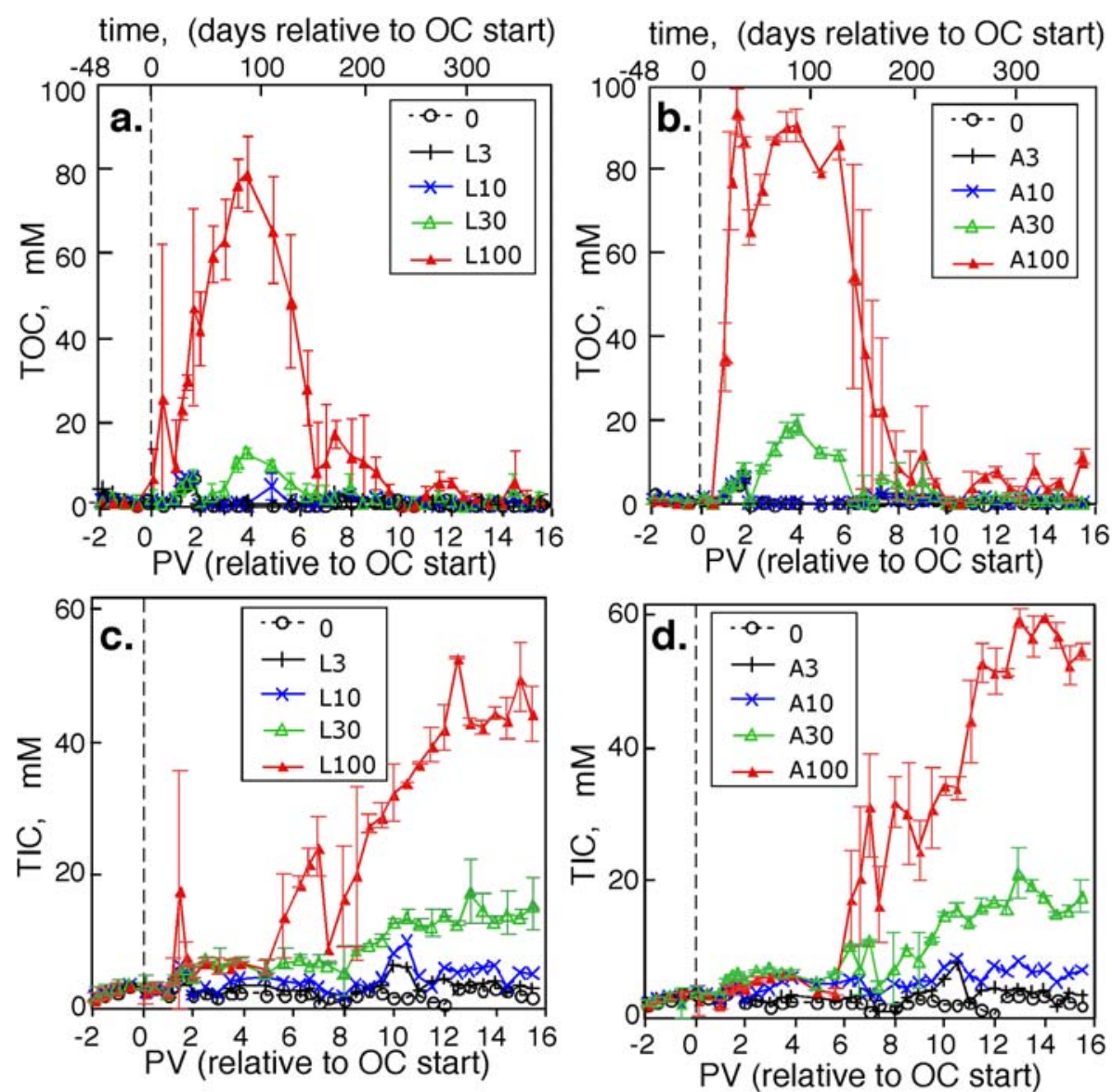

Figure 2. Time trends in effluent carbon concentrations. (a.) Effluent OC concentrations in columns supplied with lactate. (b.) Effluent OC concentrations in columns supplied with acetate. (c.) Effluent IC concentrations in columns supplied with lactate. (d.) Effluent IC concentrations in columns supplied with acetate. Range bars indicate standard deviations.

Uranium. Time trends in effluent $U$ concentrations showed strong dependence on the OC supply rate, but insignificant differences with respect to OC type. At equimolar C supply rates of lactate and acetate, time trends in effluent [U] were very similar (Figures $3 \mathrm{a}$ and $3 \mathrm{~b}$ ). The greater variability among $U$ concentrations in duplicates of lactate-treated sediments (Figure 3a) appears to have resulted from periodic stopping of flow when one set of these columns was sent to 
synchrotron facilities for X-ray absorption spectroscopy (XAS) measurements (13). All columns treated at the two highest OC supply concentrations (30 and $100 \mathrm{mM}$ ) exhibited rapid declines in [U], followed by transient increases back to intermediate concentrations. This phenomenon was identified in our previous study (6), where we showed that U(IV) was reoxidized, and hypothesized that a residual reactive Fe(III) or Mn(II,IV) phase persisted long enough to drive U(IV) reoxidation. Manganese XAS analyses on a subset of the present sediment columns showed that $\mathrm{Mn}(\mathrm{III}, \mathrm{IV})$ phases were fully reduced to $\mathrm{Mn}$ (II), and thus unlikely to drive the observed U(IV) reoxidation (13). Iron and U XAS results from that study support transient $\mathrm{U}(\mathrm{IV})$ reoxidation by $\mathrm{Fe}(\mathrm{III})$.

Complex effects of OC supply rate on effluent $U$ concentrations were reproducibly observed in both the lactate- and acetate-treated sediments. The supply rates of 0.04 and 0.14 mmol OC $\mathrm{kg}^{-1}$ day $^{-1}$ (3 and $10 \mathrm{mM} \mathrm{OC}$ ) were insufficient for generating strongly reducing conditions, but resulted in proportional increases in bicarbonate (IC) concentrations (Figures 2c,d) which drove more U(VI) into the effluent (Figures 3a,b). Thus, at lower rates of OC supply, effluent $\mathrm{U}$ concentrations increase relative to control conditions $(0 \mathrm{mM} \mathrm{OC})$ through

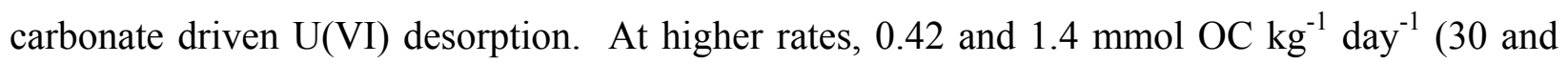
$100 \mathrm{mM} \mathrm{OC}$ ), strongly reducing conditions are established, and the lower solubility of U(IV) causes effluent $\mathrm{U}$ concentrations to decrease. However, the resulting proportionally higher IC concentrations still drive $\mathrm{U}(\mathrm{VI})$ desorption and enhance solubility of important aqueous $\mathrm{U}(\mathrm{VI})$ species. Therefore, the highest levels of OC supplied generated the highest IC levels and supported elevated $\mathrm{U}(\mathrm{VI})$ concentrations in reducing effluents. Thus lowest effluent $\mathrm{U}$ concentrations were achieved with the intermediate rate of OC supply ( $30 \mathrm{mM}$ solutions, 0.42 mmol OC kg ${ }^{-1}$ day $\left.^{-1}\right)$, not with the highest rate (100 mM solutions, $\left.1.4 \mathrm{mmol} \mathrm{OC} \mathrm{kg}^{-1} \mathrm{day}^{-1}\right)$. 

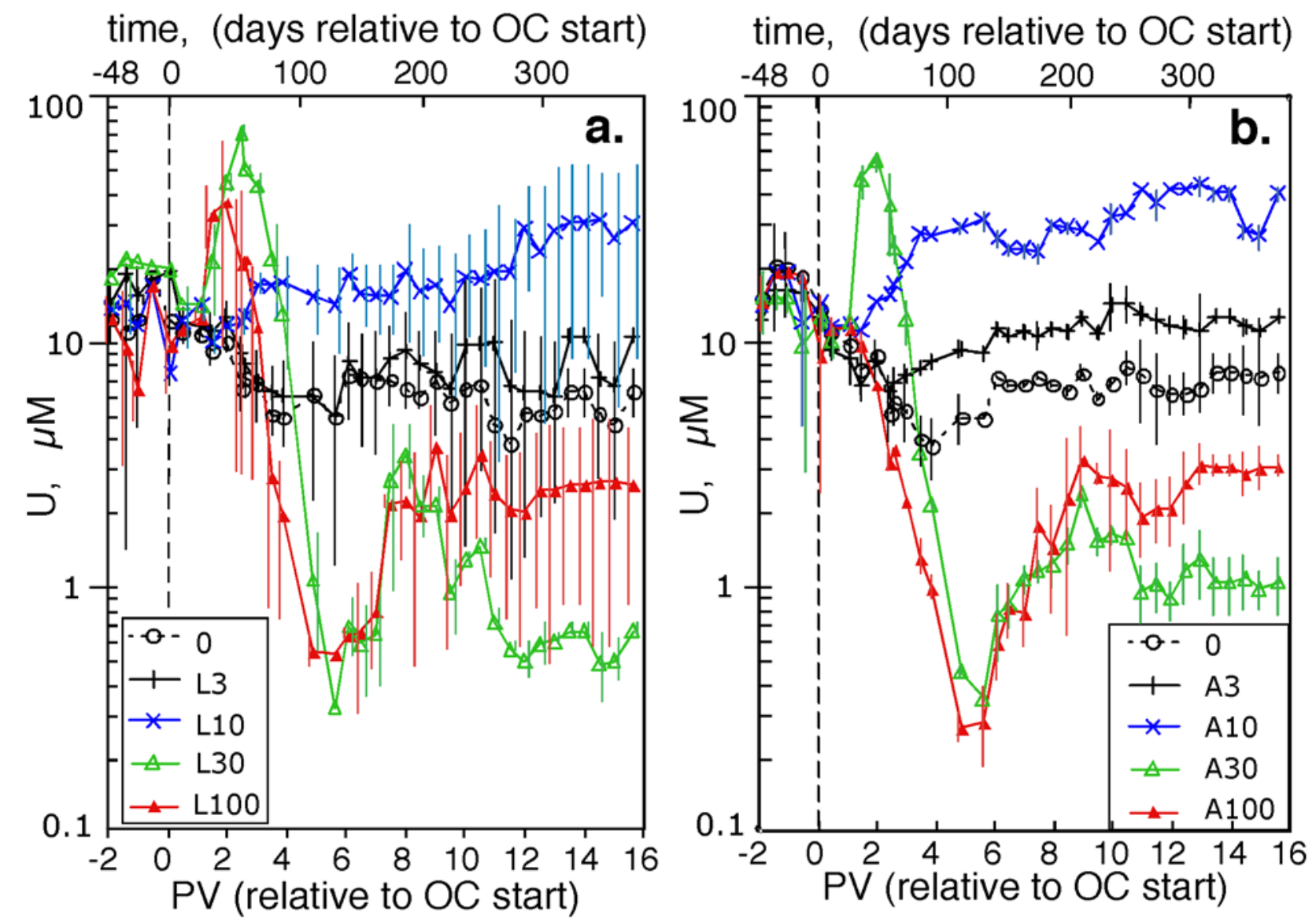

Figure 3. Time trends in effluent uranium concentrations in sediment columns supplied with (a.) lactate, and (b.) acetate. Range bars indicate standard deviations.

Geochemical calculations. The hypothesis that OC oxidation and increased bicarbonate concentrations were responsible for elevating aqueous U(VI) concentrations was further examined through equilibrium geochemical calculations with $\mathrm{P}_{\mathrm{CO} 2}$ used as the independent variable. The approximately steady-state geochemistry of these sediments and effluents were separated into cases; one where $\mathrm{U}(\mathrm{VI})$ reduction was insignificant $(0,3,10 \mathrm{mM} \mathrm{OC})$, and the other where $\mathrm{U}(\mathrm{VI})$ reduction was important $(30,100 \mathrm{mM}$ OC). Comparisons between equilibrium calculations and measured characteristic steady-state effluent $U$ concentrations are 
shown in Figures $4 \mathrm{a}$ and $4 \mathrm{~b}$ for oxidizing and reducing conditions, respectively. Modeled total aqueous $\mathrm{U}$ concentrations were not expected to closely match measured effluent $\mathrm{U}$ concentrations because of the approximations employed, and because no parameters were adjusted. More important in these comparisons are the fairly good agreements between calculated and measured trends for the $\mathrm{P}_{\mathrm{CO} 2}$-dependence of effluent $\mathrm{U}$ concentrations. Model predictions show large increases aqueous $\mathrm{U}$ with increased $\mathrm{P}_{\mathrm{CO} 2}$, under both oxidizing and reducing conditions, in good agreement with experiments. The MCL for $\mathrm{U}$ is exceeded over all environmentally relevant levels of $\mathrm{P}_{\mathrm{CO} 2}$ under oxidizing conditions (Figure 4a), and even under reducing conditions when $\mathrm{P}_{\mathrm{CO} 2}$ becomes elevated (Figure $4 \mathrm{~b}$ ). The predicted importance of aqueous $\mathrm{U}(\mathrm{VI})$ complexes with carbonate and $\mathrm{Ca}$ in these types of effluents was supported by laser fluorescence spectroscopy in an earlier study (6). It should be noted that while the laboratory experiments and associated calculations are specific to a U-contaminated sediment from Oak Ridge National Laboratory, the impact of IC on U geochemistry are much more generally important, especially in the circum-neutral to alkaline range of $\mathrm{pH}$ found in many environments. When data on key parameters are available, more complex biogeochemical modeling can be used to efficiently predict U-OC-IC dynamics over a broader range of conditions. 

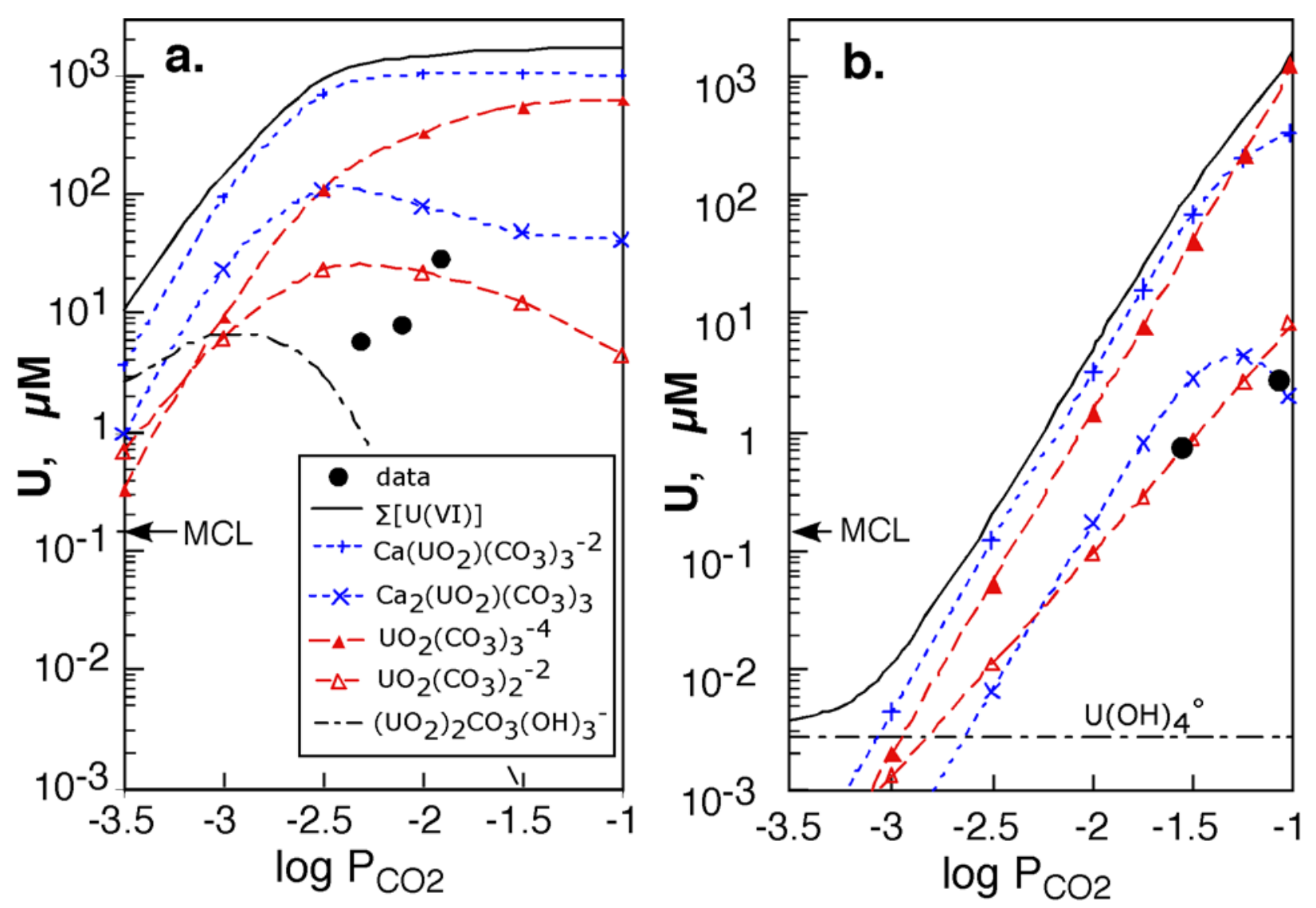

Figure 4. Calculated effects of increased $\mathrm{CO}_{2}$ partial pressure from $\mathrm{OC}$ oxidation under (a.) oxidizing conditions ( $\mathrm{pe}=11.96, \mathrm{Ca}^{2+}=2.0 \mathrm{mM}$ ), and $(\mathbf{b}$.$) reducing conditions ( \mathrm{pe}=-3.23$ to $3.35, \mathrm{Ca}^{2+}=0.4 \mathrm{mM}$, equilibrium with $\left.\mathrm{UO}_{2}(\mathrm{am})\right)$. Only concentrations of dominant species and total calculated $U$ are plotted for comparison with trends in measured $U$ concentrations. Under both conditions, increased $\mathrm{P}\left(\mathrm{CO}_{2}\right)$ allows higher aqueous $\mathrm{U}$ concentrations.

Microbial Communities. To evaluate the relationship between the composition of the bacterial communities and the observed remobilization of bioreduced $U$ we used an ordination technique, nonmetric multidimensional scaling (NMDS). The ordination plots of the total bacterial community, the iron-reducing bacteria (FRB) and the sulfate-reducing bacteria (SRB) are presented in supporting information (Figure S1). NMDS Axis 1 and Axis 2 ordination scores 
were regressed against effluent $\mathrm{U}$ concentrations, local and average redox values and effluent IC concentrations (Table 1). Significant correlations were found between the total bacterial community composition and local column Eh $\left(\mathrm{R}^{2}=0.85\right)$, average column Eh $\left(\mathrm{R}^{2}=0.69\right)$ and effluent IC $\left(\mathrm{R}^{2}=0.27\right)$ along NMDS axis 2 ; but there was no significant relationship between bacterial community composition and effluent $U$ concentrations. Parallel analysis of the FRB community revealed significant relationships with local column Eh $\left(\mathrm{R}^{2}=0.90\right)$ and average column Eh $\left(\mathrm{R}^{2}=0.71\right)$ and the composition of the FRB community along NMDS axis 1 . Again, no significant relationship could be detected between the FRB community and effluent $U$ concentrations. Similarly, analysis of the SRB community found significant relationships with local column Eh $\left(\mathrm{R}^{2}=0.51\right)$ and average column Eh $\left(\mathrm{R}^{2}=0.48\right)$ and the composition of the SRB community along NMDS axis 1 . No significant relationship could be detected between the SRB community and effluent $\mathrm{U}$ concentrations.

Remobilization of bioreduced $U$ does not appear to be directly associated with bacterial community composition. This is consistent with the remobilization of bioreduced uranium being primarily dependent on the concentration of bicarbonate. The balance between bioreduction and bicarbonate-dependent remobilization must depend on the capacity of the bacterial community to initially reduce $\mathrm{U}$ and sustain its reduction. However, following Fe(III)-catalyzed re-oxidation of $\mathrm{U}(\mathrm{IV})$, subsequent $\mathrm{U}(\mathrm{VI})$ bioreduction may be inhibited by the formation of stable $\mathrm{Ca}-\mathrm{U}-\mathrm{CO}_{3}$ complexes (6) that are thought to be less energetically-favorable as electron acceptors (27). This may tip the balance in favor of bicarbonate-dependent remobilization independent of microbial community composition. 


\begin{tabular}{|c|c|c|c|}
\hline & & NMDS axis 1 & NMDS axis 2 \\
\hline & variable & $\mathrm{R}^{2}$ & $\overline{\mathrm{R}^{2}}$ \\
\hline \multirow[t]{4}{*}{ Bacterial Community } & Eh local & 0.00 & $0.85^{* * *}$ \\
\hline & Eh average & 0.01 & $0.69^{* * *}$ \\
\hline & IC & 0.05 & $0.27 *$ \\
\hline & $\mathrm{U}$ & 0.21 & 0.13 \\
\hline \multirow[t]{4}{*}{ FRB Community } & Eh local & $0.90^{* * *}$ & 0.02 \\
\hline & Eh average & $0.71 * * *$ & 0.00 \\
\hline & IC & 0.15 & 0.00 \\
\hline & $\mathrm{U}$ & 0.15 & 0.16 \\
\hline \multirow[t]{4}{*}{ SRB Community } & Eh local & $0.51 * *$ & 0.03 \\
\hline & Eh average & $0.48 * *$ & 0.02 \\
\hline & IC & 0.13 & 0.11 \\
\hline & $\mathrm{U}$ & 0.04 & 0.17 \\
\hline
\end{tabular}

Table 1. Relationship between community compositions and local redox conditions (Eh local), average column redox (Eh average), effluent total inorganic carbon (IC) and effluent uranium (U). Significance indicated by $* \mathrm{p}<0.05, * * \mathrm{p}<0.01, * * * \mathrm{p}<0.001$

Implications. This study shows that establishment of $U$ bioreduction and maintenance of low aqueous $\mathrm{U}$ concentrations in contaminated sediments is strongly dependent on the rate of OC supply because OC oxidation results in dual impacts on U mobility. At low rates of OC supply, OC oxidation to IC, increased stability of aqueous U(VI) carbonate complexes, IC-driven U(VI) desorption, and negligible $\mathrm{U}(\mathrm{VI})$ reduction lead to significant increases in aqueous U(VI) concentrations. At higher rates of OC delivery, U(VI) reduction to much less soluble U(IV) is important, resulting in decrease aqueous $\mathrm{U}(\mathrm{VI})$ concentrations at intermediate rates of OC 
supply. However, increased OC supply invariably promotes formation of soluble U(VI)carbonates, thereby driving aqueous $\mathrm{U}(\mathrm{VI})$ concentrations higher, even while maintaining Ureducing conditions. Even under optimal rates of OC supply (between 0.14 and $1.4 \mathrm{mmol}$ OC $\mathrm{kg}^{-1} \mathrm{day}^{-1}$ in this system), initial rapid decreases in soluble U(VI) are followed with large transient increases when terminal electron acceptors are present. Some common Fe(III) (hydr)oxides capable of driving U(IV) oxidation $(6,28,29)$ can be important obstacles to immediate establishment of $U$ reduction. Subsurface microorganisms play two roles in this bioreduction-remobilization process. First, specific populations mediate the reduction of U(VI) to $\mathrm{U}(\mathrm{IV})$. As consumers of the $\mathrm{OC}$ supplied, the heterotrophic community produces $\mathrm{CO}_{2}$ which then drives $\mathrm{U}(\mathrm{VI})$ complexation and increases aqueous $\mathrm{U}(\mathrm{VI})$ concentrations. We find no evidence supporting direct involvement of microbial catalysts in reoxidation of U(IV). However, the net re-mobilization of $\mathrm{U}(\mathrm{VI})$ may be partly due to diminished microbial reduction of the less energetically-favorable calcium-uranyl-carbonate complexes that result from elevated IC. The high sensitivity to OC delivery rate indicates that $\mathrm{U}$ bioreduction will not be a simple

remediation procedure to implement. Finally, the extremely long half-life of ${ }^{238} \mathrm{U}\left(4.5 \times 10^{9}\right.$ years) needs to be considered in evaluating the sustainability of OC-based in-situ $\mathrm{U}$ remediation.

\section{Acknowledgments}

We thank Andrew Mei for technical assistance, Brian Viani (Simbol Mining Corporation) for suggesting the presentation shown in Figure $4 \mathrm{~b}$, and helpful comments from the anonymous reviewers. Funding was provided through the Environmental Remediation Sciences Program (ERSP) of the U. S. Department of Energy, under Contract No. DE-AC02-05CH11231. 


\section{Supporting Information Available}

Total elemental analyses and chemical extracts of the initial sediment are provided in Table S1. Representative effluent chemical composition data are presented in Table S2. Key thermodynamic and surface complexation parameters are listed in Table S3 and S4, respectively. Iron-reducing bacteria used in ordination are listed in Table S5. Sulfate-reducing bacteria used in ordination are listed in Table S6. NMDS ordinations are presented in Figure S1. Additional information about DNA extraction and quantification methods are included. This material is available free of charge via the Internet at http://pubs.acs.org.

\section{Literature Cited}

(1) Lovley, D. R.; Phillips, E. J. P.; Gorby, Y. A.; Landa, E. R. Microbial reduction of uranium. Nature 1991, 350, 413-416.

(2) Anderson, R. T.; Vrionis, H. A.; Ortiz-Bernad, I.; Resch, C. T.; Long, P. E.; Dayvault, R.; Karp, K.; Marutzky, S.; Metzler, D. R.; Peacock, A.; White, D. C.; Lowe, M.; Lovley, D. R. Stimulating the in situ activity of Geobacter species to remove uranium from the groundwater of a uranium-contaminated aquifer. Applied and Environmental Microbiology 2003, 69, 5884-5891.

(3) Wall, J. D.; Krumholz, L. R. Uranium reduction. Annual Review of Microbiology 2006, $60,149-166$.

(4) Lovley, D. R.; Roden, E. E.; Phillips, E. J. P.; Woodward, J. C. Enzymatic iron and uranium reduction by sulfate-reducing bacteria. Marine Geology 1993, 113, 41-53.

(5) Abdelouas, A.; Lutze, W.; Nuttall, H. E. Oxidative dissolution of uraninite precipitated on Navajo sandstone. Journal of Contaminant Hydrology 1999, 36, 353-375. 
(6) Wan, J.; Tokunaga, T. K.; Brodie, E. L.; Wang, Z.; Zheng, Z.; Herman, D. J.; Hazen, T.

C.; Firestone, M. K.; Sutton, S. R. Reoxidation of bioreduced uranium under reducing conditions. Environmental Science and Technology 2005, 39, 6162-6169.

(7) Brodie, E. L.; DeSantis, T. Z.; Joyner, D. C.; Baek, S. M.; Larsen, J. T.; Anderson, G. L.; Hazen, T. C.; Richardson, P. M.; Herman, D. J.; Tokunaga, T. K.; Wan, J. M.; Firestone, M. K. Application of a high-density oligonucleotide microarray approach to study bacterial population dynamics during uranium reduction and reoxidation. Applied and Environmental Microbiology 2006, 72, 6288-6298.

(8) Wan, J.; Tokunaga, T. K.; Kim, Y.; Brodie, E.; Daly, R.; Hazen, T. C.; Firestone, M. K. Effects of organic carbon supply rates on mobility of previously bioreduced uranium in a contaminated sediment. Environ. Sci. Technol. 2008, in press.

(9) Petrie, L.; North, N. N.; Dollhopf, S. L.; Balkwill, D. L.; Kostka, J. E. Enumeration and characterization of iron(III)-reducing microbial communities from acidic subsurface sediments contaminated with uranium(VI). Applied and Environmental Microbiology 2003, 69, 7467-7479. (10) Wu, W. M.; Carley, J.; Gentry, T.; Ginder-Vogel, M. A.; Fienen, M.; Mehlhorn, T.; Yan, H.; Caroll, S.; Pace, M. N.; Nyman, J.; Luo, J.; Gentile, M. E.; Fields, M. W.; Hickey, R. F.; Gu, B.; Watson, D.; Cirpka, O. A.; Zhuo, J.; Fendorf, S.; Kitanidis, P. K.; Jardine, P. M.; Criddle, C. S. Pilot-scale in situ bioremediation of uranium in a highly contaminated aquifer. 2. Reduction of U(VI) and geochemical control of U(VI) bioavailability. Environmental Science and Technology 2006, 40, 3986-3995.

(11) Gu, B.; Wu, W. M.; Ginder-Vogel, M. A.; Zhou, J.; Fendorf, S.; Criddle, C. S.; Jardine, P. M. Bioreduction of uranium in a contaminated soil column. Environmental Science and Technology 2005, 39, 4841-4847. 
(12) Ganesh, R.; Robinson, K. G.; Reed, G. D.; Sayler, G. S. Reduction of hexavalent uranium from organic complexes by sulfate- and iron-reducing bacteria. Applied and Environmental Microbiology 1997, 63, 4385-4391.

(13) Tokunaga, T. K., Wan, J., Kim, Y., Sutton, S. R., Newville, M., Lanzirotti, A., Rao, W. Real-time X-ray absorption spectroscopy of uranium, iron, and manganese in contaminated sediments during bioreduction. Environmental Science and Technology 2008, 42, 2839-2844.

(14) Parkhurst, D. L.; Appelo, C. A. J. User's Guide to PHREEQC (Version 2)--A Computer Program for Speciation, Batch-Reaction, One-Dimensional Transport, and Inverse Geochemical Calculations. http://wwwbrr.cr.usgs.gov/projects/GWC_coupled/phreeqc/ 2005.

(15) Guillaumont, R.; Fanghanel, T.; Fuger, J.; Grenthe, I.; Neck, V.; Palmer, D. A.; Rand, M. H.; Mompean, F. J.; Illemassene, M.; Domenechi-Orti, C. Update on the Chemical Thermodynamics of Uranium, Neptunium, Plutonium, Americium, and Technicium. Elsevier 2003.

(16) Dong, W. M.; Brooks, S. C. Determination of the formation constants of ternary complexes of uranyl and carbonate with alkaline earth metals $(\mathrm{Mg} 2+, \mathrm{Ca} 2+, \mathrm{Sr} 2+$, and $\mathrm{Ba} 2+)$ using anion exchange method. Environmental Science and Technology 2006, 40, 4689-4695.

(17) Kohler, M.; Curtis, G. P.; Meece, D. E.; Davis, J. A. Methods for estimating adsorbed uranium(VI) and distribution coefficients of contaminated sediments. Environmental Science and Technology 2004, 38, 240-247.

(18) Barnett, M. O.; Jardine, P. M.; Brooks, S. C. U(VI) adsorption to heterogeneous subsurface media: Application of a surface complexation model Environmental Science and Technology 2002, 36, 937-942. 
(19) Dzombak, D. A.; Morel, F. M. M. Surface Complex Modeling-Hydrous Ferric Oxide.; Wiley: New York, 1990.

(20) Appelo, C. A. J.; van der Weiden, M. J. J.; Tournassat, C.; Charlet, L. Surface complexation of ferrous iron and carbonate on ferrihydrite and the mobilization of arsenic. Environmental Science and Technology 2002, 36, 3096-3103.

(21) Payne, T. E. In Uranium (VI) interactions with mineral surfaces: Controlling factors and surface complexation modelling; University of New South Wales: School of Civil and Environmental Engineering, 1999; Vol. Ph. D. thesis, p 332.

(22) Missana, T.; Garcia-Gutierrez, M.; Fernandez, V. Uranium (VI) sorption onto colloidal magnetite under anoxic environment: Experimental study and surface complexation modelling. Geochimica Cosmochimica Acta 2003, 67, 2543-2550.

(23) Lovley, D. R.; Holmes, D. E.; Nevin, K. P. Dissimilatory Fe(III) and Mn(IV) Reduction Advances in Microbial Physiology 2004, 49, 219-286.

(24) Rabus, R.; Hansen, T. A.; Widdel, F. Dissimilatory Sulfate- and Sulfur-Reducing Prokaryotes. In The Prokaryotes; Dworkin, M., Ed.; Springer, 2006.

(25) R Development Core Team; R Foundation for Statistical Computing: Vienna, Austria, 2005.

(26) Oksanen, J.; Kindt, R.; O'Hara, B. The vegan package http://cc.oulu.fi/ jarioksa/softhelp/vegan.html 2005.

(27) Brooks, S. C.; Fredrickson, J. K.; Carrol, S. L.; Kennedy, D. W.; Zachara, J. M.; Plymale, A. E.; Kelly, S. D.; Kemner, K. M.; Fendorf, S. Inhibition of bacterial U(VI) reduction by calcium. Environmental Science and Technology 2003, 37, 1850-1858. 
(28) Sani, R. K.; Peyton, B. M.; Amonette, J. E.; Geesey, G. G. Reduction of uranium(VI) under sulfate-reducing conditions in the presence of Fe(III)-(hydr)oxides. Geochimica Cosmochimica Acta 2004, 68, 2639-2648.

(29) Ginder-Vogel, M.; Criddle, C. S.; Fendorf, S. Thermodynamic constraints on the oxidation of biogenic UO2 by Fe(III) (hydr)oxides. Environmental Science and Technology 2006, 40, 3544-3550. 
Brief: Supplying organic carbon to sediments contaminated with $\mathrm{U}(\mathrm{VI})$ has opposing effects of increasing concentrations of soluble U-carbonate complexes and reduction to less soluble U(IV). 